\title{
Effect of eggshell powder fortification on the physicochemical and organoleptic characteristics of muffins
}

\author{
Faiqa Afzal, Ghulam Mueen-ud-Din, Muhammad Nadeem*, Mian
} Anjum Murtaza and Shahid Mahmood

Institute of Food Science and Nutrition, University of Sargodha, Sargodha-Pakistan

*Corresponding author's email: mnadeemft@gmail.com

Citation

Faiqa Afzal, Ghulam Mueen-ud-Din, Muhammad Nadeem, Mian Anjum Murtaza and Shahid Mahmood. Effect of eggshell powder fortification on the physicochemical and organoleptic characteristics of muffins. Pure and Applied Biology. Vol. 9, Issue 2, pp1488-1496. http://dx.doi.org/10.19045/bspab.2020.90154

\begin{tabular}{llll}
\hline \hline Received: 26/12/2019 & Revised: 25/02/2020 & Accepted: 06/03/2020 & Online First: 10/03/2020 \\
\hline \hline
\end{tabular}

\section{Abstract}

The present study was designed to overcome the deficiency of calcium by preparation of muffins with eggshell powder. By dietary invention such as food fortification calcium deficiency can be reduced. Bakery products are best source for fortification of food. The eggshell powder was added for fortification of muffins at 8 and $16 \mathrm{~g} / 500 \mathrm{~g}$ flour basis, synthetic source of calcium carbonate was also added in muffins at the same level. Minerals estimation indicated increasing trend of most of the minerals. Proximate analysis of muffins indicated increasing trend in ash, fiber and protein content but decrease in moisture, nitrogen free extract and fat content significantly $(\mathrm{p}<0.05)$ with progressive substitution of eggshell powder. Organoleptic properties in term of color, flavor, taste, texture, mouth feel and overall acceptability were only acceptable at control and minimum level of eggshell powder. Muffins $\left(\mathrm{T}_{1}\right)$ with $8 \mathrm{~g}$ egghell powder showed significant increase in mineral contents like calcium $(2462.7 \pm 0.69 \mathrm{mg} / 100 \mathrm{~g})$, magnesium $(5.65 \pm 0.28 \mathrm{mg} / 100 \mathrm{~g})$, potassium $(2.99 \pm 0.33 \mathrm{mg} / 100 \mathrm{~g})$, sodium $(6.94 \pm 0.48 \mathrm{mg} / 100 \mathrm{~g})$, and iron $(1.26 \pm 0.53 \mathrm{mg} / 100 \mathrm{~g})$ as well as improved sensory chracteristics but other attributes showed no difference in the quality attributes of muffins fortified with eggshell compared with control.

Keywords: Calcium; Deficiency; Egg shell; Fortification; Muffins

\section{Introduction}

Poultry eggs are very healthy food items" nutritious and economical but their shells collected from different sources like house, hotels, and also from fast food industries are discarded. According to the Food and agriculture organization, the global production of eggs in 2013 had reached a volume of about 68 million tonnes FAO [1]. About $11 \%$ of recorded yield of shell was reported from the total egg weight, thus the waste being produced around 6.82 million per year worldwide can be estimated [2], this possess a serious environmental problem. Chicken eggshell is a source of calcium that can be used as calcium supplementation. Fresh and fossilized eggshell are used to get calcium salt [3]. Eggshell contains nearly $40 \%$ calcium, whereas magnesium $(\mathrm{Mg})$ and phosphorus $(\mathrm{P})$ is present at the concentration about $(0.5$ to $0.1 \%)$ respectively $[4,5]$. According to body weight calcium is present around 1 to $2 \%$ and from total mineral contents $39 \%$ of the body $[6,7]$. Deficiency of micronutrients that seems to be less but critical are stated as "Hidden Hunger". 
Calcium is a crucial mineral compulsory for cell permeability, hormone secretion, neuromuscular functioning, enzyme activation, bone development, coagulation and several other intracellular and extracellular tasks [8], its deficiency leads toward weak bone health and teeth, osteoporosis and also minimizes the capacity of blood clotting and numerous other symptoms [9]. Due to the insufficient consumption of calcium the widespread incidence of osteoporosis is a real threat to the world [10].

Milk and dairy products like cheese, yogurt and milk are the main sources of calcium and regular ingestion of these products regulate dietary calcium levels [11]. Grains, some green vegetables and fruits, calcium-fortified soymilk, kale, and broccoli, some roots and legumes, and calcium-fortified fruit drinks are also the good sources of calcium. Natural sources of calcium are more significant because they contain not only calcium but other elements such as phosphorus and iron. Eggshell powder (ESP) is equal to purified calcium carbonate regarding calcium content, which is extensively used because of its higher calcium content [3].

Addition of micronutrients intentionally in the food is known as fortification, it aids in elimination of several communal diseases such as anemia, osteoporosis and rickets; it also shows an important role by providing adequate quantity of nutrients to the body [12]. For fortification of food numerous sources of calcium are accessible [13]. Moreover, calcium fortification by eggshell powder is the part of several studies, food such as pasta, cake fermented milk and others [14-18]. Eggshell contains high amount of calcium in the form of calcium carbonate and calcium phosphate $(98.43 \%$ and $0.75 \%)$ respectively [19]. For fortification of flour a lot of bakery industries which produce waste eggs shell can be used as a source of calcium. From adults to kids of every age group, muffin is a good option in our routine diet like during the snack meals, breakfast time, tea breaks and parties, their consumption and significance can be differentiated by its existence as a substantial food item [20].

\section{Materials and methods}

Commercially available wheat flour (Maida), milk, salt, ghee, eggshells, sugar, eggs, and were purchased from the local market of Sargodha. This study was conducted at the Institute of Food Science and Nutrition, University of Sargodha, Sargodha, Pakistan. The eggshell powder and calcium fortified muffins were prepared by following procedure given in (Fig. 1, Table 1), respectively and treatment plan in (Table 2).

\section{Preparation of eggshell powder}

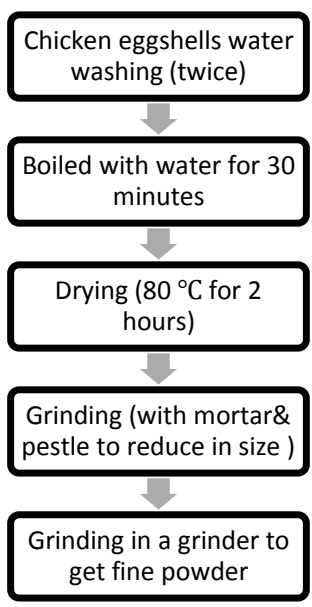

Figure 1. Preparation of Eggshell Powder [21] 
Table 1. Recipe for the preparation of muffins [22]

\begin{tabular}{|c|c|}
\hline Ingredients & Quantity \\
\hline Flour & $500 \mathrm{~g}$ \\
\hline Butter & $350 \mathrm{~g}$ \\
\hline Sugar & $300 \mathrm{~g}$ \\
\hline Milk & $30 \mathrm{~mL}$ \\
\hline Baking powder & $15 \mathrm{~g}$ \\
\hline Salt & $2 \mathrm{~g}$ \\
\hline Eggs & 7 number \\
\hline Eggshell powder & 8 and $16 \mathrm{~g}$ \\
\hline Calcium carbonate & 8 and $16 \mathrm{~g}$ \\
\hline
\end{tabular}

Table 2. Variable Formulations of Eggshell Calcium Fortified Muffins (Treatment plan)

\begin{tabular}{|c|c|c|c|c|}
\hline Treatments & Eggshell powder & Eggshell powder & Calcium carbonate & Calcium carbonate \\
\hline $\mathrm{T}_{0}$ & - & - & - & \\
\hline $\mathrm{T}_{1}$ & 8 & - & - & - \\
\hline $\mathrm{T}_{2}$ & - & 16 & - & - \\
\hline $\mathrm{T}_{3}$ & - & - & 8 & - \\
\hline $\mathrm{T}_{4}$ & - & - & - & 16 \\
\hline
\end{tabular}

*amounts are given in gram $(\mathrm{g})$

Proximate analysis of flour and eggshell powder fortified Muffins

The flour and eggshell calcium fortified muffins were exposed to proximate analysis using the method of AACC [23]. The moisture content of flour and eggshell calcium fortified muffins was determined according to AACC method No. 44-15A [23]. The protein content was determined by AACC permitting to the Kjeldahl's method No. 46-30 by using Kjeltech Apparatus [23]. Crude fat content of flour and eggshell calcium fortified muffin according to AACC method No. 30-25 was determined by using Soxhlet apparatus [23]. Crude fiber content of flour and eggshell fortified muffins was estimated by AACC method No. 32-10 as given in [23] in Labconco Fibertech (Labconco Corporation Kansas, USA). The ash content of flour and eggshell calcium fortified muffin was estimated according to AACC method No. 08-01 [23]. Nitrogen free extract was determined by subtracting the sum of percentages of protein, fiber, fat, ash and moisture from 100.

\section{Determination of mineral contents}

For mineral profile, straight grade flour and eggshell powder were analyzed freshly at 0 day. Calcium, Sodium, Iron, Magnesium and Potassium were determined. Samples were prepared for mineral estimation by using wet digestion method. From every treatment $(0.5$ g) was taken and digested in a $100 \mathrm{~mL}$ conical flask on hot plate to digest with 10 $\mathrm{mL}$ nitric acid, heat at $70^{\circ} \mathrm{C}$ for 20 minutes, after this it was digested with $5 \mathrm{~mL}$ per chloric acid $(60 \%)$ at $190^{\circ} \mathrm{C}$ till the point when all the content of flask becomes clear. Then for every sample the volume was made $100 \mathrm{~mL}$ with de-ionized water and the obtained samples were transferred to $100 \mathrm{~mL}$ volumetric flasks. In the end these samples were filtered. These filtered samples were run by Atomic Absorption Spectrophotometer (Model: AA-6300). To obtain standard curves, the samples of known strength were first run, then the mineral contents such as calcium, iron, potassium, sodium, phosphorus and magnesium in raw material were determined using these respective curves as describe in AACC [23]. 


\section{Sensory Evaluation}

The sensory characters for evaluation of muffins were included texture, flavor, taste, color and overall acceptability and were analyzed by expert panel using nine point hedonic scales [24].

\section{Statistical Analysis}

All the obtained results from different parameters were analyzed by SAS 10.1 software to statistical analysis of variance (ANOVA) technique to determine the difference in the mean values by significance and non-significant differences [25].

\section{Results and discussion}

\section{Proximate composition}

The moisture content was observed as $13.33 \pm 0.60 \%$ in straight grade flour. The obtained values are justified by the study [26]. It was observed that the mean values of moisture content to be $21.29 \pm 0.68 \%, 17.56$ $\pm 0.75 \%, \quad 15.80 \pm 0.78 \%, 20.18 \pm 0.65 \%$ and $18.59 \pm 0.93 \%$ for $\mathrm{T}_{0}$ (control), $\mathrm{T}_{1}$ with $8 \%$ and $\mathrm{T}_{2}$ with $16 \%$ eggshell powder fortified muffins like-wise $\mathrm{T}_{3}$ with $8 \%$ and $\mathrm{T}_{4}$ with $16 \%$ calcium carbonate - fortified muffins respectively. It was observed that as the eggshell concentration increases moisture content was decreased. According to study the pattern for moisture content showed in unleavened and leavened breads decreased as the concentration of calcium source increased [27].

In Straight grade flour the amount of protein was $(11.01 \pm 0.73 \%)$. Our results were matched and it was also reported that the protein contents of wheat flour are 10.32$11.58 \%$ [26]. Fortification of eggshell powder in muffins at various concentrations increased the crude protein content as the protein value of $\mathrm{T}_{0}$ control, $\mathrm{T}_{1}$ with $8 \%$ eggshell powder $\mathrm{T}_{2}$ with $16 \%$ eggshell powder, $\mathrm{T}_{3}$ with $8 \%$ calcium carbonate and $\mathrm{T}_{4}$ with $16 \%$ calcium carbonate fortified muffins with their mean values are $11.77 \pm 0.28 \%, 13.50 \pm 0.40 \%, 14.70 \pm 0.62 \%$, $11.61 \pm 0.56 \%$ and $11.52 \pm 0.51 \%$, respectively. The protein value increased as the eggshell fortification increased because in eggshell powder protein $(3.92 \%)$ is also present $[28,29]$.

The fat amount in straight grade flour was $0.84 \pm 0.25 \%$. Study showed the fat content in wheat flour $0.42 \%$ [30]. Fat content in our results are less than another result who reported that the fat content in wheat flour was $(1.81 \%)$ [31]. Fat content in muffins significantly decreased as being observed in $\mathrm{T}_{0}, \mathrm{~T}_{1}, \mathrm{~T}_{2}, \mathrm{~T}_{3}$ and $\mathrm{T}_{4}$ with their mean values $(35.86 \pm 0.82 \%)$, $(33.85 \pm 0.58 \%)$, $(34.31 \pm 0.75 \%)$, (35.54 $0.56 \%$ ) and in eggshell fortified muffins $\mathrm{T}_{2}$ with $16 \%$ eggshell powder showed that as the amount of eggshell powder increases, fat content decreases. The obtained results matched with the studies that the fat content was increased in supplemented bread made with whole wheat flour due to the maximum fat content present in tertiary buck wheat flour containing Calcium Carbonate [32].

The fiber content in Straight grade flour was $0.84 \pm 0.27 \%$. Our results were in line with the results who detected fiber content in wheat flour $(0.82 \%)$ [33]. The effect of treatments were found to be non-significant on the fiber content of muffins. Our results were in line with other results [34]. The effect of treatments was found to be highly significant on the ash content of the muffins. Ash content of muffins fortified with eggshell and calcium carbonate at various levels showed a significant increase, high level of ash was observed in $\mathrm{T}_{2}$ with $16 \%$ eggshell powder as $(4.60 \pm 0.39 \%)$ followed by $\mathrm{T}_{1}(4.27 \pm 0.43 \%)$ and $\mathrm{T}_{3}(3.57 \pm 0.43 \%)$ and $\mathrm{T}_{4}(3.42 \pm 0.44)$ and the lowest in $\mathrm{T}_{0}$ control with $(1.20 \pm 0.26 \%)$ (Table 3). The amount of ash obtained from study result was $(1.51 \pm 0.51 \%)$, higher mineral content present in food means give out the maximum amount of ash [35]. Increase in ash content $(1.5 \%)$ and $(3.3 \%)$ in breads prepared from wheat flour that were 
fortified with defatted soy flour at (3\%) and $(7 \%)$ respectively, as compared to unfortified (control) [36]. Nitrogen free extract contents were present in flour $(68.26 \pm 1.44 \%)$. The highest Nitrogen free extract content was found in $\mathrm{T}_{0}(48.75 \pm 0.89 \%)$ followed by $\mathrm{T}_{3}$
$(48.33 \pm 0.96 \%)$ and $\mathrm{T}_{4}(47.56 \pm 1.16 \%)$ and the lowest in $\mathrm{T}_{2}(46.31 \pm 0.85 \%)$ followed by $\mathrm{T}_{1}(46.20 \pm 1.03 \%)$. fortification of wheat flour with mash bean and mung bean decreased the level of Nitrogen free extract [37].

Table 3. Proximate composition (\%) of SGF and eggshell fortified muffins (mean values \pm SD)

\begin{tabular}{|c|c|c|c|c|c|c|}
\hline Treatment & Moisture & Protein & Fat & Fiber & Ash & $\begin{array}{c}\text { Nitrogen } \\
\text { free extract }\end{array}$ \\
\hline $\begin{array}{c}\text { Straight } \\
\text { grade flour }\end{array}$ & $13 . .33 \pm 0.60$ & $11.01 \pm 0.73$ & $0.84 \pm 0.25$ & $0.84 \pm 0.27$ & $1.51 \pm 0.51$ & $68.26 \pm 1.44$ \\
\hline $\mathbf{T}_{\mathbf{0}}$ & $21.29 \pm 0.68$ & $11.77 \pm 0.28$ & $35.86 \pm 0.82$ & $1.28 \pm 0.70$ & $1.20 \pm 0.26$ & $48.75 \pm 0.89$ \\
\hline $\mathbf{T}_{\mathbf{1}}$ & $17.56 \pm 0.75$ & $13.50 \pm 0.40$ & $34.31 \pm 0.75$ & $1.54 \pm 0.41$ & $4.26 \pm 0.43$ & $46.20 \pm 1.03$ \\
\hline $\mathbf{T}_{\mathbf{2}}$ & $15.80 \pm 0.78$ & $14.70 \pm 0.62$ & $33.85 \pm 0.58$ & $1.76 \pm 0.20$ & $4.60 \pm 0.39$ & $46.31 \pm 0.85$ \\
\hline $\mathbf{T}_{\mathbf{3}}$ & $20.18 \pm 0.65$ & $11.61 \pm 0.56$ & $35.54 \pm 0.56$ & $0.91 \pm 0.35$ & $3.57 \pm 0.43$ & $48.33 \pm 0.96$ \\
\hline $\mathbf{T}_{\mathbf{4}}$ & $18.59 \pm 0.93$ & $11.52 \pm 0.51$ & $35.50 \pm 0.61$ & $1.01 \pm 0.36$ & $3.42 \pm 0.44$ & $47.56 \pm 1.16$ \\
\hline
\end{tabular}

\section{Minerals Content}

Higher calcium content was observed in eggshell powder $(66711.05 \pm 111.1 \mathrm{mg} / 100 \mathrm{~g})$ and it was also good in magnesium $(11.50 \pm 0.36 \mathrm{mg} / 100 \mathrm{~g})$, sodium $(1.93 \pm 0.29$ $\mathrm{mg} / 100 \mathrm{~g})$, Iron $(1.24 \pm 0.37 \mathrm{mg} / 100 \mathrm{~g})$ and potassium $(1.05 \pm 0.26 \mathrm{mg} / 100 \mathrm{~g})$. The highest mineral component in eggshell (225.35 $\mathrm{mg} / 100 \mathrm{~g}$ ) was calcium and then phosphorus, magnesium, and iron [4, 38]. Calcium content of flour was estimated as $580.61 \pm 0.66 \mathrm{mg} / 100 \mathrm{~g}$ (Table 4). Our values copared with study who stated that calcium content of wheat flour was $23 \mathrm{mg} / 100 \mathrm{~g}$ [26]. It was estimated that Calcium content of muffins increased by the increase in amount of eggshell, high level of calcium was observe in $\mathrm{T}_{2}$ with $16 \%$ eggshell powder $(3846.30 \pm 0.85 \mathrm{mg} / 100 \mathrm{~g})$ and the lowest in $\mathrm{T}_{0}$ control $(631.31 \pm 0.60 \mathrm{mg} / 100 \mathrm{~g})$. Calcium content of brownies products can also be increased by the chicken eggshells [39].

Magnesium content in flour was estimated $(5.51 \pm 0.37 \mathrm{mg} / 100 \mathrm{~g})$ (Table 4). It was estimated that magnesium content of muffins was also increased by the increase in amount of eggshell, high level was observed in $\mathrm{T}_{2}$ with $16 \%$ eggshell powder as $(6.11 \pm 0.38$ $\mathrm{mg} / 100 \mathrm{~g}$ ) and the lowest amount in $\mathrm{T}_{0}$ control $(3.81 \pm 0.38 \mathrm{mg} / 100 \mathrm{~g})$. Study showed that in whole wheat flour based bread at all three levels fortified with egg shell powder showed the highest magnesium concentration [4].

Potassium content of flour was estimated $(4.76 \pm 0.28 \mathrm{mg} / 100 \mathrm{~g})$ (Table 4). Potassium content of muffins with eggshell powder and calcium carbonate was significantly decreased at various levels. Potassium content with their mean values of $\mathrm{T}_{0}$ control, $\mathrm{T}_{1}$ with $8 \%$ eggshell powder, $\mathrm{T}_{2}$ with $16 \%$ eggshell powder, $\mathrm{T}_{3}$ with $8 \%$ calcium carbonate and $\mathrm{T}_{4}$ with $16 \%$ calcium carbonate were estimated $(3.14 \pm 0.55 \mathrm{mg} / 100 \mathrm{~g})$, $(2.99 \pm 0.33 \mathrm{mg} / 100 \mathrm{~g}),(3.08 \pm 0.37 \mathrm{mg} / 100 \mathrm{~g}$, $(4.17 \pm 0.35 \mathrm{mg} / 100 \mathrm{~g})$ and $(4.42 \pm 0.24$ $\mathrm{mg} / 100 \mathrm{~g}$ ) respectively. Related results were found from another study [40].

Sodium content was estimated $(0.51 \pm 0.39$ $\mathrm{mg} / 100 \mathrm{~g}$ ) (Table 4). As the amount of eggshell increased, the sodium content of muffins also increased, high level was observed in $\mathrm{T}_{2}$ with $16 \%$ eggshell powder $(7.56 \pm 0.49 \mathrm{mg} / 100 \mathrm{~g}), \mathrm{T}_{1}$ with $8 \%$ eggshell powder $(6.94 \pm 0.48 \mathrm{mg} / 100)$ and lowest sodium content in $\mathrm{T}_{0}$ control as $(2.70 \pm 0.41$ 
$\mathrm{mg} / 100 \mathrm{~g})$. At the levels of 10 and $20 \%$ eggshell fortification of cake, significantly increased its calcium contents with a perceptible proliferation in sodium [41]. Iron content found in flour was estimated $(0.70 \pm 0.52 \mathrm{mg} / 100 \mathrm{~g})$ (Table 4). Study showed iron content was present in flour (3.3 $\mathrm{mg} / 100 \mathrm{~g}$ ) [42]. Iron content of muffins fortified with eggshell powder showed a significant increase by the increase in amount of eggshell, high level of Iron in $\mathrm{T}_{2}$ with $16 \%$ eggshell powder $(1.39 \pm 0.46 \mathrm{mg} / 100 \mathrm{~g})$ and lowest amount was found in $\mathrm{T}_{0}$ control $(0.64 \pm 0.39 \mathrm{mg} / 100 \mathrm{~g})$. By fermentation process phytic acid was reduced, which results in high availability of minerals [32, 43].

Table 4. Mineral contents (mg/100g) of SGF, eggshell powder and eggshell fortified muffins

\begin{tabular}{|c|c|c|c|c|c|}
\hline Treatment & Calcium & Magnesium & Potassium & Sodium & Iron \\
\hline $\begin{array}{c}\text { Straight grade } \\
\text { flour }\end{array}$ & $580.61 \pm 0.66$ & $5.51 \pm 0.37$ & $4.76 \pm 0.28$ & $0.51 \pm 0.39$ & $0.700 \pm .52$ \\
\hline $\begin{array}{c}\text { Eggshell } \\
\text { powder }\end{array}$ & $66711.05 \pm 111.13$ & $11.50 \pm 0.36$ & $1.05 \pm 0.26$ & $1.93 \pm 0.29$ & $1.24 \pm 0.37$ \\
\hline $\mathbf{T}_{\mathbf{0}}$ & $631.31 \pm 0.60$ & $3.81 \pm 0.29$ & $3.14 \pm 0.55$ & $2.70 \pm 0.41$ & $0.64 \pm 0.39$ \\
\hline $\mathbf{T}_{\mathbf{1}}$ & $2462.7 \pm 0.69$ & $5.65 \pm 0.28$ & $2.99 \pm 0.33$ & $6.94 \pm 0.48$ & $1.26 \pm 0.53$ \\
\hline $\mathbf{T}_{\mathbf{2}}$ & $3846.3 \pm 0.85$ & $6.11 \pm 0.38$ & $3.08 \pm 0.37$ & $7.56 \pm 0.49$ & $1.39 \pm 0.46$ \\
\hline $\mathbf{T}_{\mathbf{3}}$ & $2046.4 \pm 0.93$ & $4.49 \pm 0.31$ & $4.17 \pm 0.35$ & $5.52 \pm 0.42$ & $1.17 \pm 0.44$ \\
\hline $\mathbf{T}_{\mathbf{4}}$ & $3144.3 \pm 1.10$ & $4.53 \pm 0.38$ & $4.42 \pm 0.24$ & $5.86 \pm 0.39$ & $1.24 \pm 0.35$ \\
\hline
\end{tabular}

\section{Sensory Evaluation}

The color scores of muffins fortified with eggshell powder and calcium carbonate at various levels were estimated as 7.8, 7.6, 7.4, 6.7 and 6.3 in different treatments. Supplementation of chicken eggshell did not offer the influence to the color of biscuits, for the reason that eggshells have whitish color [44]. An increase in flavor scores of muffins was observed. The flavor score of muffins in which eggshell powder was added was slightly superior to that of standard muffins [45]. The highest taste score was found in $T_{0}$ control (7.8) followed by $\mathrm{T}_{2}$ with $16 \%$ eggshell powder (7.7) and the lowest score was achieved by $\mathrm{T}_{4}$ with $16 \%$ calcium carbonate (7.3). The taste score of muffins with eggshell fortification were same as compared to control [32]. The highest texture score was observed in eggshell fortified muffins in $\mathrm{T}_{2}$ with $16 \%$ eggshell powder
(7.7), followed by $\mathrm{T}_{1}$ with $8 \%$ eggshell powder (7.6) and the minimum taste was observed in $\mathrm{T}_{4}$ with $16 \%$ calcium carbonate. The texture score of muffins with eggshell powder addition was slightly superior to that of standard muffins [46]. The highest mouth feel score was found in $\mathrm{T}_{0}$ control (7.8) followed by $\mathrm{T}_{1}$ with $8 \%$ eggshell powder (7.7) and the lowest of $\mathrm{T}_{2}$ with $16 \%$ eggshell powder (6.6). The highest overall acceptability score were observed in eggshell fortified muffins in $\mathrm{T}_{0}$ control (7.6) followed by $\mathrm{T}_{3}$ with $8 \%$ calcium carbonate (7.5) and the minimum overall acceptability was observed in $\mathrm{T}_{2}$ with $16 \%$ eggshell powder (Table 5). The better flavor, color and overall acceptability was found in the bread with eggshell powder (ESP) as compared to control bread; though the taste and flavor stayed alike or became inferior as reported by [47]. 
Table 5. Sensory evaluation of eggshell fortified muffins

\begin{tabular}{|c|c|c|c|c|c|c|}
\hline Treatment & Color & Flavor & Taste & Texture & Mouth feel & Overall acceptability \\
\hline $\mathbf{T}_{\mathbf{0}}$ & 7.8 & 7.5 & 7.8 & 7.5 & 7.8 & 7.6 \\
\hline $\mathbf{T}_{\mathbf{1}}$ & 7.6 & 7.7 & 7.6 & 7.6 & 7.6 & 7.4 \\
\hline $\mathbf{T}_{\mathbf{2}}$ & 7.4 & 7.8 & 7.7 & 7.7 & 6.6 & 7.3 \\
\hline $\mathbf{T}_{\mathbf{3}}$ & 6.7 & 7.3 & 7.5 & 7.4 & 7.3 & 7.5 \\
\hline $\mathbf{T}_{\mathbf{4}}$ & 6.3 & 7.2 & 7.3 & 7.3 & 7.1 & 7.4 \\
\hline
\end{tabular}

\section{Conclusion}

It was concluded that eggshell powder increased the mineral contents such as calcium, magnesium, sodium and iron except potassium. Sensory characteristics were high like flavor and taste but other attributes showed no more difference in the quality of fortified muffins as compared to control. However, more overall acceptability was of $\mathrm{T}_{0}$ but also for eggshell fortified muffins and synthetic calcium carbonate with lower amounts. High amount of eggshell powder fortified muffins were not much liked by the panel. It is suggested that nutritional benefits of eggshell calcium fortification can encourage the acceptability through education and public enlightenment. Treatment $\mathrm{T}_{1}$ with $8 \mathrm{~g}$ eggshell powder is recommended for fortification of bakery products.

\section{Authors' contributions}

Conceived and designed the experiments: F Afzal, GM Din \& M Nadeem, Performed the experiments: F Afzal, Analyzed the data: M Nadeem, Contributed materials/ analysis/ tools: GM Din, MA Murtaza \& S Mahmood, Wrote the paper: F Afzal \& M Nadeem.

\section{References}

1. FAO (Food and Agriculture Organization of the United Nations) (2016). http://www. fao.org/(Accessed 9 May 2017).

2. Boron L (2004). Citrato de cálcio da casca do ovo: biodisponibilidade e uso como suplemento alimentar. UFSC, Florianópolis.

3. Kärkkäinen MU, Wiersma JW \& LambergAllardt CJ (1997). Postprandial parathyroid hormone response to four calcium-rich foodstuffs. The Am J Clin Nutri 65(6): 1726-1730.

4. Schaafsma A, Pakan I, Hofstede GJH, Muskiet FA, Van Der Veer E \& De Vries PJF (2000). Mineral, amino acid, and hormonal composition of chicken eggshell powder and the evaluation of its use in human nutrition. Poultry Sci 79(12):18331838.

5. Milbradt BG, da Silva JS, Silveira AS, Dutra LDO, Pereira, RDR, Callegaro MDGK \& Emanuelli T (2017). Eggshell fractions containing different particle sized affect mineral absorption but not bone mineral retention in growing rats. Int $J$ Food Sci Nutr 68(2): 210-218.

6. Cashman KD (2002). Calcium intake, calcium bioavailability and bone health. $\mathrm{Br}$ J Nutr 87(S2): S169-S177.

7. Institute of Medicine (US) Standing Committee on the Scientific Evaluation of Dietary Reference Intakes (1997). Dietary reference intakes for calcium, phosphorus, magnesium, vitamin $\mathrm{D}$, and fluoride. National Academies Press (US).

8. Pu F, Chen N \& Xue S (2016). Calcium intake, calcium homeostasis and health. Food Sci and Human Wellness 5(1): 8-16.

9. Meschino J (2002). Calcium: requirements, bioavailable forms, physiology and clinical aspects. Dyn Chiropr 20, 18.

10. Heaney RP (2000). Calcium, dairy products and osteoporosis. J Am Coll Nutr 19(sup2): 83S-99S.

11. Caroli A, Poli A, Ricotta D, Banfi G \& Cocchi D (2011). Invited review: Dairy intake and bone health: A viewpoint from the state of theart1. J Dairy Sci 94(11): 5249-5262. 
12. Sadighi J, Mohammad K, Sheikholeslam R, Amirkhani M, Torabi P, Salehi F \& Abdolahi Z (2009). Public Health 123, 794.

13. Faine MP (1995). Dietary factors related to preservation of oral and skeletal bone mass in women. $J$ Prosthet Dent 73(1): 65-72.

14. Daengprok W, Garnjanagoonchorn W \& Mine Y (2002). Fermented pork sausage fortified with commercial or hen eggshell calcium lactate. Meat Sci 62(2): 199-204.

15. Naves MMV, Fernandes DC, Prado CMM \& Teixeira LSM (2007). Food fortification with egg shell powder as a calcium source. Food Sci and Technol 27(1): 99-103.

16. Salem IS, Ammar ASM \& Habiba RA (2012). Effect of eggshell powder addition as a source of calcium fortification on butter cake quality. J Agric Vet Sci 5:109118.

17. Brun LR, Lupo M, Delorenzi DA, Di Loreto VE \& Rigalli A (2013). Chicken eggshell as suitable calcium source at home. Int J Food Sci Nutr 64(6): 740-743.

18. Fina BL, Brun LR \& Rigalli A (2016). Increase of calcium and reduction of lactose concentration in milk by treatment with kefir grains and eggshell. Int J Food Sci Nutr 67(2): 133-140.

19. Rois Mansur A (2013). UGM Students Successfully Utilize Eggshell Waste into Poultry Feed.

20. Akoh CC (1998). Fat replacers. Food Technology (USA).

21. Suzuki FK, Wang PY, Weatherspoon JB, \& Mead LC (2014). US. Patent No. $8,859,010$. Washington, DC: US. Patent and Trademark Office.

22. Yaseen T, Ashraf I, Ali S \& Pasha I (2012). Development and nutritional evaluation of date bran muffins. Food Sci Nutr 2(1).

23. AACC (2000). Approved Methods of American Association of Cereal Chemists. The American Association of Cereal Chemist, St. Pauls, Minnessota, USA.

24. Land DG \& Shepherd R (1988). Scaling and ranking methods. In: Sensory Analysis of Foods. Piggott, J. R. (Ed.). Elsevier Applied Science, New York. pg. 155-185.
25. Steel RGD, Torrie JH \& Dickey DA (1997). Principles and Procedures of Statistics. A biometrical approach. 3rd Ed. McGraw Hill Book Co. New York, USA.

26. Ahmed MSH, Mohie MK, Nefisa AH \& Abo El-Nor SAH (2013). Effect of Wheat Flour Supplemented with Barely and/or Corn Flour on Barley Bread Quality. Pol J Food Nutr Sci 63: 11-18.

27. Khan MR, Wahab S, QAZI I, Ayub M, Muhammad A, Uddin Z \& Noor M (2017). Effect of Calcium Fortification on Whole Wheat Flour Based Leavened and Unleavened Breads by Utilizing Food Industrial Wastes. Asian J Chem 29(2).

28. Yongcheng L, Michael B, Clive LI, Gary M \& Wang K (2013). Eggshell powder compositions and methods of producing eggshell powder compositions Publication number: WO 2013075003 A1.

29. Anjum FM, Ahmad I, Butt MS, Sheikh MA \& Pasha I (2005). Amino acid composition of spring wheats and losses of lysine during chapati baking. J Food Compost Anal 18(6): 523-532.

30. Ajani AO, Oshundahunsi OF, Akinoso R, Arowora KA, Abiodun AA \& Pessu PO (2012). Proximate composition and sensory qualities of snacks produced from breadfruit flour. Global Journal of Science Frontier Research Biological Sciences (GJFSR) 12(7): 1-9.

31. Baljeet SY, Ritika BY, \& Roshan LY (2010). Studies on functional properties and incorporation of buckwheat flour for biscuit making. Int Food Res J 17(4).

32. Bano R, Hussain S, Li J, Ali S, Jin W, Li H, Ali A \& Hussain (2014). M Food Sci Qual Manage 34, 78.

33. Horsfall D, Mepba, LE \& Nwaojigwa SU (2007). Chemical composition, functional and baking properties of wheat-plantain composite flours, Afri J Food Agri Nutr Dev 7: 1684-5374.

34. Chauhan GS \& Sharma HR (2000). Physico-chemical and rheological quality characteristics of fenugreek (Trigonella foenum graecum L.) supplemented wheat flour. J Food Sci Tech 37(1): 87-90. 
35. Klava D (2004). Improvement of nutritive value of wheat bread. Summary of promotion work for acquiring doctor's degree. Latvia University of Agriculture Faculty, Jelgava, Latvia

36. Mashayekh M, Mahmoodi MR \& Entezari MH (2008). Effect of fortification of defatted soy flour on sensory and rheological properties of wheat bread. Int J Food Sci Tech 43(9): 1693-1698.

37. Riaz A, Wahab S, Hashmi MS \& Shah AS (2007). The influence of mungbean and mashbean supplementation on the nutritive value of whole wheat flour bread. Sarhad J Agric 23(3): 737.

38. Siulapwa N, Mwambungu A, Lungu E \& Sichilima W (2014). Nutritional value of four common edible insects in Zambia. Int J Sci Res 3(60): 876-884.

39. Meikawati W \& Suyanto A (2014). Uji Organoleptik Tepung Dan Brownies Berbahan Dasar Tepung Mocaf (Modified Cassava Flour) Terfortifikasi Kalsium Dari Cangkang Telur Ayam Ras. In Prosiding Seminar Nasional \& Internasional.

40. El-Shobery MA, Mansour AIA, \& Zaki KG (2012). Studies on using of date syrup (Dibis) in yoghurt making. Minia J Agric Res Dev 32(1): 177-194.
41. Makai F \& Chudacek J (1991). The treatment of osteoporosis with Biomin-H. Arch Gerontol Geriat 487-490.

42. Watt BK \& Merrill AL (1975). Agriculture Handbook No. 8. US Govt. Printing Office, Washington D.C., USA.

43. Qazi IM, Wahab S, Shad AA, Zeb A \& Ayuab M (2003). Effect of different fermentation time and baking on phytic acid content of whole-wheat flour bread. Asian J Plant Sci 2(8): 597-601.

44. Hasan MN, Miah MM, Islam MS, Alam QM \& Hossain MI (2008). Change and instability in area and production of wheat and maize in Bangladesh. Bangladesh $J$ Agr Res 33(3): 409-417

45. Lindquist EF (1940). Statistical analysis in educational research.

46. Butt MS, Nasir M, Akhtar S \& Sharif K (2004). Effect of moisture and packaging on the shelf life of wheat flour. Int $J$ of Food Safety 4(1): 1-6.

47. Bradauskiene V, Montrimaite K \& Moscenkova E (2017). Facilities of bread enrichment with calcium by using eggshell powder. In 11th Baltic Conference on Food Science and Technology" Food science and technology in a changing world" Foodbalt 2017, Jelgava, Latvia, 27-28 April 2017 (pp 91-95). Latvia University of Agriculture. 